\title{
PENINGKATAN MUTU SKL SISWA SMK MELALUI MODEL YANG BERORIENTASI PADA KEMAMPUAN PERANCANGAN DAN MELAKUKAN EKSPERIMEN UNTUK MELATIH KETRAMPILAN BERPIKIR KRITIS
}

\author{
Siti Annijat Maimunah \\ Fakultas Ilmu Tarbiyah dan Keguruan Universitas Islam \\ Negeri Maulana Malik Ibrahim Malang
}

\begin{abstract}
The legislation System of national education No. 20 Year 2003 about education standards consist of standard content, processes, the competence of graduates, educational personnel, infrastructure, management, financing and assessment of education.

Standards of competence and standard of graduates, Graduates in Vocational secondary schools are expected to have the ability to build Standard and competence of graduates of the creative, and innovatively in decision making. The reality of the situation of vocational high school graduates do not meet the standard of competence of Graduates, because the existence of limited practical tools so that the experiment also rarely do.

The purpose of the study is to describe the practicality, and the effectiveness of the implementation of the model of learning ability-oriented design and conduct experiments to practice critical thinking skills of students of SMK.

As for the approach of this study is a descriptive qualitative. Based on the results of the implementation of the developed learning the real device, it can be concluded that the ability of the design-oriented learning and experimentation to train creative and critical thinking skills a valid, practical, effective, and can enhance critical thinking skills and creative as well as achieving perfection results of student learning. Positive student response after follow learning by applying the learning abilityoriented device design and perform experiments to practice critical thinking skills and creative students.
\end{abstract}

Key words: quality improvement of the standard of competence of graduates of vocational high school Students, the ability of Designing and performing experiments, Thinking Skills 
Abstrak: Undang-Undang Sistem pendidikan Nasional No 20 Tahun 2003 tentang standar nasional pendidikan terdiri atas standar isi, proses, kompetensi lulusan, tenaga kependidikan, sarana dan prasarana, pengelolaan, pembiayaan dan penilaian pendidikan.

Standar Kompetensi Lulusan dan Standar Lulusan, di SMK diharapkan memiliki kemampuan untuk membangun dan Standar Kompetensi Lulusan kreatif, dan innovativ dalam pengambilan keputusan. Kenyataan dilapangan lulusan Sekolah Menengah Kejuruan belum memenuhi Standar Kompetensi Lulusan, sebab adanya keterbatasan alat praktikum sehingga eksperimen juga jarang dilakukan.

Tujuan penelitian ini yaitu mendeskripsikan kepraktisan, dan keefektifan pelaksanaan model pembelajaran yang berorientasi pada kemampuan perancangan dan melakukan eksperimen untuk melatih keterampilan berpikir kritis siswa SMK.

Adapun pendekatan penelitian ini adalah deskriptif kualitatif. Berdasarkan hasil implementasi perangkat pembelajaran yang dikembangkan dilapangan, dapat disimpulkan bahwa perangkat pembelajaran berorientasi pada kemampuan perancangan dan melakukan eksperimen untuk melatih ketrampilan berpikir kritis dan kreatif yang valid, praktis, efektif, dan dapat meningkatkan keterampilan berpikir kritis dan kreatif serta mencapai ketuntasan hasil belajar siswa. Respon siswa positif setelah mengikuti pembelajaran dengan menerapkan perangkat pembelajaran berorientasi pada kemampuan perancangan dan melakukan eksperimen untuk melatih ketrampilan berpikir kritis dan kreatif siswa.

Kata-Kata Kunci: Peningkatan Mutu Standar Kompetensi Lulusan Siswa Sekolah Menengah Kejuruan, Kemampuan Perancangan dan Melakukan Eksperimen, Ketrampilan Berpikir 
Siti Annijat Maimunah - Peningkatan Mutu SKL Siswa SMK Melalui Model yang Berorientasi pada Kemampuan Perancangan dan Melakukan Eksperimen untuk Melatih Ketrampilan Berpikir Kritis

\section{Pendahuluan}

UU Sisdiknas No 20 Tahun 2003 tentang standar nasional pendidikan terdiri atas standar isi, proses, kompetensi lulusan, tenaga kependidikan, sarana dan prasanana, pengelolaan, pembiayaan dan penilaian pendidikan.

SKL dan SL, di SMK diharapkan memiliki kemampuan untuk membangun dan menerapkan informasi dan pengetahuan secara logis, kritis, kreatif, dan innovativ dalam pengambilan keputusan. Untuk itu diperlukan latihan eksperimen untuk membangun kompetensi lulusan yang baik

Kenyataan dilapangan lulusan SMK belum memenuhi SKL, sebab adanya keterbatasan alat praktikum sehingga eksperimen juga jarang dilakukan. Hal tersebut seharusnya dilembaga-lembaga sekolah kejuruhan dilengkapi dengan alat-alat praktik serba laboratorium sehingga melalui eksperimen mereka memiliki kompetensi yang memadai.

Eksperimen memliki peran penting dalam menentukan ketrampilan proses sains siswa dan membimbing siswa berpikir kritis dan sistematis dalam menyelesaikan masalah yang disajikan. Eksperimen dapat diterapkan untuk menyelesaikan masalah yang dihadapi sehari-hari. Melalui eksperimen siswa akan memperoleh pengalaman langsung.

Pembelajaran dengan alat peraga yang sederhana dapat menghasilkan kompetensi yang lebih baik dibandingkan tanpa alat peraga (Supramono, 2000: 83-92). Jadi praktikum harus dikaitkan dengan kehidupan siswa sehari-hari, meskipun dengan alat peraga (media) yang sangat sederhana. Hal tersebut karena siswa akan mendapatkan pengalaman dan ketrampilan menggunakan alat peraga tersebut, meskipun amat sangat sederhana.

Proses ilmiah adalah cara memperoleh pengetahuan melalui observasi dan melakukan eksperimen, kemampuan melakukan pengukuran, menguji hipotesis, merancang eksperimen, mengambil dan mengolah data, interpretasi data dan dapat mengkomunikasikan hasil eksperimen tersebut. Akan tetapi kenyataannya lulusan SMK tidak demikian. Hal ini mungkin ada anggapan bahwa lulusan SMK hanya dipersiapkan untuk bekerja di pabrik/industri saja yang tidak memerlukan ketrampilan sains. Padahal ketrampilan proses sains akan membentuk ketrampilan motorik dan kognitif yang dapat membimbing dan melatih siswa untuk berpikir kritis, jadi siswa SMK tidak hanya harus suka di bengkel saja. 
Siti Annijat Maimunah - Peningkatan Mutu SKL Siswa SMK Melalui Model yang Berorientasi pada Kemampuan Perancangan dan Melakukan Eksperimen untuk Melatih Ketrampilan Berpikir Kritis

\section{Model Pembelajaran Berbasis Praktik}

Praktik yang artinya pelaksanaan secara nyata apa yangdisebut dalam teori. Sedangkan pratikum adalah bagian dari pengajaran yang bertujuan agar siswa mendapat kesempatan untuk menguji dan melaksanakan di keadaan nyata, apa yangdiperoleh dari teori dan pelajaran praktik. Menurut Sudirman metode praktikum adalah cara penyajian pelajaran kepada siswa untuk melakukan percobaandengan mengalami dan membuktikan sesuatu yang dipelajari. Hal ini didukung pula oleh-inatapura yang menyatakan bahwa metode praktikum adalah suatu cara penyajian yang disusun secara aktif untuk mengalami dan membuktikan sendiri tentang apayang dipelajarinya. Melalui praktikum, peserta didik dapat memiliki banyak pengalaman, baik berupa pengamatan langsung atau bahkan melakukan percobaan sendiri dengan objek tertentu. Tidak diragukan lagi bahwa melalui pengalaman langsung (first-hand experiences), peserta didik dapat belajar lebih mudah dibandingkan dengan belajar melalui sumber sekunder, misalnya buku. Hal tersebut sangat sesuai dengan pendapat Bruner yang menyatakan bahwa anak belajar dengan pola active melalui perbuatan (learning by doing) akan dapat mentrasnfer ilmu pengetahuan yang dimilikinya pada berbagai situasi (Resna Sastrawijaya). Pembelajaran berbasis praktikum pada dasarnya adalah pembelajaran yang berpusat pada praktikum. Menurut Kloper praktikum merupakan bagian yang sangat penting dalam suatu kegiatan pembelajaran,khususnya pembelajaran sains. Hal ini antara lain karena kegiatan praktikum dapat meningkatkan kemampuan dalam mengorganisasi, mengkomunikasi, dan menginterpretasikan hasil observasi. Rustaman mengemukakan bahwa dalam pendidikan sains kegiatan laboratorium (praktikum) merupakan bagian integral dari kegiatan belajar mengajar, khususnya biologi. Hal ini menunjukkan betapa pentingnya peranan kegiatan praktikum untuk mencapai tujuan pendidikan sains.

\section{Kerangka Berpikir Kritis}

Berpikir adalah kemampuan untuk menganalisis, mengkritik, dan mencapai kesimpulan berdasarkan inferensi atau jugment yang baik (Arends, 2008). Pemikiran yang baik selalu memiliki dimensi kritis, dimensi kreatif, dan dimensi kepedulian, kepedulian tidak hanya berarti empati untuk orang lain melainkan juga terhdap lingkungan sekitar (Lipman dalam Wegerif, 2010). Berpikir tingkat tinggi sering mendapatkan multiple solution, masing-masing dengan kerugian dan keuntungannya masing-masing, dan bukan sebuah solusi tunggal. 
Tempat yang tepat untuk melatihkan ketrampilan berpikir dan memcahkan masalah-masalah adalah sekolah. Sekolah merupakan cermin dari masyarakat luas dan kelas merupakan laboratorium pemecahan masalah dari suatu kehidupan yang nyata. Dengan demikian sekolah menjadi tempat untuk melatihkan dan membiasakan cara berpikir kritis sehingga siswa akan memiliki kemampuan sebagai problem solver (Dewey 1916) dalam Nur dan Wikandari (2008). Hal tersebut sejalan dengan pendapat Ennis (1996) bahwa salah satu tujuan utama persekolahan adalah meningkatkan kemampuan siswa untuk berpikir kritis, membuat keputusan rasional tentang apa yang diperbuat atau apa yang diyakini. Menurut Sizer (1992) dalam Jhonson (2002), bahwa sekolah adalah tentang belajar untuk menggunakan pikirannya dengan baik, tentang berpikir banyak pemecahan persoalan yang penting, tentang menanamkan kebiasaan berpikir.

Berpikir tingkat tinggi membidik baik berpikir kritis maupun berpikir kreatif. Sebagian besar orang tua dan pendidik setuju bahwa dalam masyarakat modern saat ini, anak-anak harus menguasai ketrampilan berpikir dalam tingkatan yang lebih tinggi. Kemampuan berpikir dengan jelas dan imajinatif, menilai bukti, bermain logika, dan mencari alternative imajinatif dari ide-ide konvensional, memberi anak-anak muda sebuah rute yang jelas di tengah carut marut pemikiran pada zaman teknologi saat ini (Browne dan Keeley, 1990) dalam Jhonson (2002).

Menurut Jhonson (2002) berpikir kritis merupakan sebuah proses yang terarah dan jelas yang digunakan dalam kegiatan mental seperti memcahkan masalah, mengambil keputusan, membujuk, menganalisis asumsi, dan melakukan penelitian ilmiah. Berpikir kritis adalah kemampuan untuk berpendapat dengan cara yang terorganisasi. Berpikir kritis merupakan kemampuan untuk mengevaluasi secara sistematis bobot pendapat pribadi dan pendapat orang lain. Berpikir kreatif adalah kegiatan mental yang memupuk ideode asli dan pemahaman-pemahaman baru.

Berpikir kritis dan kreatif memungkinkan siswa untuk mempelajari masalah secara sistematis, menghadapi berjuta tantangan dengan cara yang terorganisasi, merumuskan pertanyaan inovatif, dan merancang solusi orisinal. Berpikir kritis dapat diuraikan sebagai metode ilmiah karena berpikir kritis mirip dengan metode penelitian ilmiah yaitu: pertanyaan diidentifikasi, hipotesis diformulasikan, data dikumpulkan, hipotesis diuji dan dievaluasi, dan kesimpulan yang dapat dipercaya dibuat dari hasil-hasil penelitian. Semua ketrampilan penelitian ilmiah dikoordinasikan oleh berpikir kritis, yang tidak lebih 
dari metode ilmiah yang digunakan dalam kehidupan sehari-hari. Berpikir kritis adalah berpikir ilmiah. Hal tersebut sesuai dengan pendapat Abruscato (1992), bahwa apabila kita menggunakan aktivitas sains yang menggunakan proses discovery, siswa akan memiliki banyak kesempatan untuk menerapkan ketrampilan berpikir kritis mereka.

Berpikir kritis saling berhubungan dengan berpikir yang lain, seperti proses pemecahan masalah, berpikir kreatif, dan pembuatan keputusan (Innabi dan Sheikh (2006) dalam Redhana (2009). Ketika seseorang memecahkan masalah, seseorang termotivasi berpikir secara kreatif untuk menghasilkan ide-ide atau mengembangkan sesuatu.

Tujuan pengajaran berpikir kritis, mendorong siswa mempertanyakan apa yang mereka dengar dan mengkaji pikiran mereka sendiri untuk memastikan tidak terjadi logika yang tidak konsisten atau keliru (Norin, 1985) dalam Nur dan Wikandari (2000). Secara sederhana dapat dikatakan bahwa dalam aktivitas berpikir kritis melibatkan penggunaan penalaran dan logika untuk memecahkan masalah. Beberapa ketrampilan yang termasuk berpikir kritis adalah: 1) membandingkan dan membedakan, yang termasuk didalamnya juga ketrampilan mengidentifikasi karakteristik dan menganalisis suatu objek; 2) menerapkan konsep; 3) interpretasi gambaran; 4) menghubungkan sebab dan akibat; 5) membuat generalisasi; 6) membuat penilaian; 7) memecahkan masalah (Forgarty \& Bellanca, 1986).

Menurut Jhonson (2002), terdapat delapan langkah yang dapat diikuti oleh pemikir kritis. Inti pertanyaan-pertanyaan yang saling berkaitan berikut ini memungkinkan siswa untuk mengevalusi pemikiran mereka sendiri dan pemikiran orang lain. Dengan menerapkan langkah-langkah ini secara rutin, akan membantu membuat berpikir kritis dapat menyatu dengan diri kita: (1) Mengungkapkan isu, masalah, keputusan, atau kegiatan yang sedang dipertimbangkan dengan jelas. (2) Sudut pandang. (3) Alasan yang diajukan. (4) Asumsi-asumsi yang dibuat. (5) Bahasa. (6) Alasan harus sesuai dengan bukti-bukti yang ada. (7) Kesimpulan. (8) Implikasi dari kesimpulan-kesimpulan yang sudah diambil.

Bayer (1998: 57) dalam Nur dan Wikandari (2000), mengidentifikasi 10 ketrampilan berpikir kritis yang dapat digunakan siswa mempertimbangkan validitas (keabsahan) tuntutan atau argument, memahami periklanan dan sebagainya, antara lain (1) Membedakan fakta-fakta yang dapat diverifikasi (diuji kebenarannya); (2) Membedakan antara informasi, tuntutan atau alasan yang relevan 
dengan yang tidak relevan; (3) Menentukan kecermatan factual (kebenaran) dari suatu pernyataan; (4) Menentukan kredibilitas (dapat dipercaya) dari suatu sumber; (5) Mengidentifikasi tuntunan atau argument yang mendua; (6) Mengidentifikasi asumsi yang tidak dinyatakan; (7) Mendeteksi bias (menemukan penyimpangan); (8) Mengidentifikasi kekeliruan-kekeliruan logika; (9) Mengenali ketidakkonsistenan logika dalam suatu alur penalaran; (10) Menentukan kekuatan suatu argumen atau tuntutan.

Ennis (1987) menyatakan kemampuan berpikir kritis terdiri atas 12 indikator, yang dapat diuraikan sebagai berikut:

1) Klarifikasi dasar, terdiri atas tiga indicator, yaitu: (1) memfokuskan pada pertanyaan, (2) menganalisis argument, dan (3) bertanya dan atau menjawab pertanyaan klarifikasi dan atau tantangan.

2) Dukungan dasar, terdiri atas dua indicator yaitu: (4) mempertimbangkan kredibilitas sumber, dan menyelidikan dan atau mempertimbangkan laporan observasi.

3) Inferensi, terdiri atas tiga indicator, yaitu: (6) membuat dan atau mempertimbangkan deduksi, (7) membuat dan atau mempertimbangkan induksi, dan (8) membuat dan atau mempertimbangkan pendapat yang bernilai.

4) Klarifikasi lanjut, terdiri atas dua indicator, yaitu: (9) mendefinisikan istilah dan atau mempertimbangkan definisi, dan (10) mengidentifikasi asumsi.

5) Strategi dan taktik, terdiri atas dua indicator, yaitu: (11) menentukan suatu tindakan, (12) berinteraksi dengan orang lain.

Santrock (2008) dalam Desmita (2009) mengajukan beberapa pedoman bagi guru dalam membantu peserta didik mengembangkan ketrampilan berpikir kritis, yaitu:

1) Guru harus berperan sebagai pemandu siswa dalam menyusun pemikiran sendiri. Guru yang berperan sebagai pemandu dalam membantu siswa menyusun pemikiran mereka sendiri harus: menghargai pertanyaan siswa; memandang siswa sebagai pemikir yang membawa teori baru tentang dunia; memahami sudut pandang siswa; mendorong siswa melakukan elaborasi jawabannya; dan memperkuat rasa ingin tahu intelektual siswa. Guru tidak boleh; memandang pikiran siswa sebagai wadah kosong dan menganggap dirinya berperan sebagai penuang 
informasi ke pikiran siswa; terlalu mengandalkan buku wajib; dan hanya mencari jawaban yang benar untuk memvalidasi pembelajaran siswa.

2) Menggunakan pertanyaan yang berbasis pemikiran. Dalam pertanyaan berbasis pemikiran, guru mengajukan pertanyaan yang menstimulasi pemikiran dan diskusi. Pertanyaanpertanyaan berbasis pemikiran yang dimasukkan dalam pengajaran akan membantu siswa mengkonstruksi pemahaman terhadap suatu topic secara lebih mendalam.

3) Membangkitkan rasa ingin tahu intelektual siswa. Mendorong siswa untuk bertanya, merenungkan, menyelidiki, dan meneliti.

4) Melibatkan siswa dalam perencanaan dan strategi. Bekerjasamalah dengan siswa dalam menyusun rencana, menentukan tujuan, mencari arah yang tepat dan mencapai hasil.

5) Member siswa model peran pemikir yang positif dan kritis. Misalnya dengan mengundang ke dalam kelas tokoh-tokoh intelektual yang terkenal memiliki pemikiran yang postif dan sangat kritis untuk menunjukkan kepada siswa bagaimana cara berpikir efektif.

6) Guru harus mampu menjadi model peran pemikir yang positif bagi siswa. Guru harus memperlihatkan bahwa ia adalah seorang pemikir yang aktif, positif, kritis, serta selalu ingin tahu.

\section{Assesmen Berpikir Kritis}

Ennis (2001) menjelaskan bahwa assesmen terhadap kemampuan berpikir kritis antara lain bertujuan untuk 1) mendiagnosis tingkat berpikir kritis siswa; 2) memberi umpan balik keberanian berpikir kritis siswa; 3) memberi motivasi agar siswa mengembangkan berpikir kritisnya; dan 4) memberi informasi kepada guru tentang pengaruh pengajarannya tentang berpikir kritis. Guru dapat membuat tes berpikir kritis dalam bentuk pertanyaan openended yang disesuaikan dengan aspek-aspek berpikir kritis khusus yang diinginkan.

Menurut Corebima (2001), aspek-aspek evaluasi yang harus diimplementasikan agar dapat mendorong perkembangan berpikir kritis antara lain: 1) Tes yang diberikan mencakup tes kognitif maupun psikomotor yang disesuaikan dengan tujuan pembelajaran; 2) untuk tes kognitif hendaknya menggunakan bentuk essay, jika menggunakan obyektif hendaknya dirancang dengan hati-hati dan digunakan dengan sangat bijaksana; 3 ) hasil tes evaluasi kognitif didasarkan pada acuan transfer atau penemuan informasi dan pada acuan tingkat berpikir 
yang termasuk ketrampilan berpikir kritis.

Pertanyaan-pertanyaan terbuka (open question) sangat baik jika dapat diterapkan, karena akan menuntut siswa untuk menjawabnya secara logis atau menggunakan penalaran seperti yang termasuk dalam indicator ketrampilan berpikir kritis. Analisis terhadap ketrampilan berpikir kritis siswa dapat dilakukan dengan memberikan skor pada hasil tes kemampuan berpikir kritis. Pemberian skor didasarkan pada skala Taksonomi Solo yang dikembangkan oleh (Biggs \& Collins, 1982 dalam Habibi, 2009). Skor yang diperoleh pada setiap soal akan dirata-rata untuk mendapatkan hasil tingkat kemampuan berpikir kritis siswa. Analisis deskriptif terhadap tingkat kemampuan berpikir kritis siswa didasarkan pada skala sebagai berikut:

\section{Skala Tingkat Berpikir Berdasarkan Taksonomi Solo}

\begin{tabular}{|c|l|}
\hline Skala & \multicolumn{1}{|c|}{ Keterangan } \\
\hline Prestuructual & $\begin{array}{l}\text { Hanya menggunakan kemampuan berpikir dasar dan } \\
\text { jawabannya tidak termasuk ke dalam permasalahan. }\end{array}$ \\
\hline Unistructural & $\begin{array}{l}\text { Jawaban dapat disimpulkan ke dalam kriteria } \\
\text { penyelesaian masalah, yaitu menggunakan proses- } \\
\text { proses berpikir dasar untuk menyelesaikan kesulitan } \\
\text { yang telah diketahui atau terdefinisi. }\end{array}$ \\
\hline Multistructural & $\begin{array}{l}\text { Jawaban dapat disimpulkan kedalam kriteria } \\
\text { pembuatan keputusan, yaitu menggunakan proses- } \\
\text { proses dasar untuk memilih respon terbaik dari } \\
\text { beberapa pilihan, mengumpulkan informasi yang } \\
\text { diperlukan dalam cakupan topic. }\end{array}$ \\
\hline Relational & $\begin{array}{l}\text { Jawaban dapat disimpulkan kedalam kriteria } \\
\text { berpikir kritis, yaitu menggunakan proses-proses } \\
\text { berpikir dasar untuk menganalisis argument dan } \\
\text { interpretasi, mengembangkan pola-pola } \\
\text { pembentukan alasan yang logis dan mengganti } \\
\text { asumsi-asumsi yang mendasari. }\end{array}$ \\
\hline
\end{tabular}

\section{Perbedaan Berpikir Kritis dan Berpikir Kreatif}

Klasifikasi Huitt's (1992) tentang teknik pemecahan masalah:

1. Berpikir kritis-linier dan berseri (berurutan), lebih terstruktur, lebih rasional dan analitik, lebih berorientasi kepada tujuan

2. Berpikir kreatif-holistik dan paralel, lebih intuitif (bisikan kalbu) dan emosional, lebih kreatif, lebih visual, dan lebih taktual/ kinestetik 
3. Klasifikasi Springer \& Deutsch's (1993) tentang dominasi lateralisasi otak:

4. Berpikir otak kiri--analitik, berseri, logis, objektif

5. Berpikir otak kanan--global, paralel, emosional, subjektif antara Berpikir Kreatif dan Berpikir Kritis

Berpikir kritis melibatkan pemikiran logis dan penalaran termasuk keterampilan seperti perbandingan, klasifikasi, pengurutan, penyebab / efek, pola, Jalinan, analogi, penalaran deduktif dan induktif, peramalan, perencanaan, hipotesa, dan mengkritisi.

Berpikir kreatif melibatkan menciptakan sesuatu yang baru atau asli, melibatkan keterampilan fleksibilitas, orisinalitas, kefasihan, elaborasi, brainstorming, modifikasi, citra, pemikiran asosiatif, daftar atribut, berpikir metaforis, serta hubungan yang kuat. Tujuan dari berpikir kreatif adalah untuk merangsang keingintahuan dan mempromosikan perbedaan.

Berpikir kritis dapat dianggap lebih berpikir menggunakan otak kiri sedangkan kreatif lebih banyak menggunakan otak kanan, kedua hal ini terlibat dalam proses "berpikir." Ketika kita berbicara tentang HOTS "higher-order thinking skills" yaitu "Kemampuan Berpikir Tingkat Tinggi " kita berkonsentrasi pada tiga tingkat atas Taksonomi Bloom: analisis, sintesis, dan evaluasi.

\section{Manfaat Berpikir Kritis dan Berpikir Kreatif}

1. Manfaat berpikir kritis

Arief Achmad, 2009, menyatakan kemampuan berpikir kritis merupakan kemampuan yang sangat esensial untuk kehidupan, pekerjaan, dan berfungsi efektif dalam semua aspek kehidupan lainnya.

Keuntungan yang didapatkan sewaktu kita tajam dalam berpikir kritis, kita bisa menilai bobot kemampuan seseorang dari perkataan yang ia keluarkan, kita juga dengan tidak gampangnya menyerap setiap informasi tanpa memikirkan terlebih dahulu hal yang sedang disampaikan. Bayangkan! Jika kita semua terbentuk dengan kebiasaan ini, bisa dipastikan akan muncul kreatifitas yang baru dan kita bisa terus menerus mengalami pertumbuhan yang lebih baik di setiap aspek dari bidang yang sedang kita tekuni.

Dengan berpikir kritis maka seseorang:

a. Terhindar dari berbagai upaya penipuan, manipulasi, pembodohan, dan penyesatan.

b. Selalu fokus pada suatu hal yang sebenarnya.

c. Hidup dalam dunia nyata daripada dunia fantasi.

d. Terhindar dari berbagai kesalahan, seperti membuang 
waktu, uang, dan melibatkan emosi dalam kepercayaan atau ajaran atau dogma atau ideologi yang salah dan menyesatkan.

e. Selalu terlibat dalam perziarahan kemanusiaan yang menarik dan menantang dalam upaya memahami diri sendiri dan dunia di mana kita berada.

f. Selalu mampu memberikan sumbangsih kemanusiaan yang nyata dan bermanfaat demi menemukan dan mengedepankan kebenaran yang didasarkan pada ilmu pengetahuan dan akal sehat.

g. Mampu menyaring semua informasi yang diperoleh dari semua sumber.

h. Mampu memperbaiki dan meningkatkan kemampuan dalam hal menjelaskan dan berargumentasi mengenai banyak topik/fenomena serta mampu meyakinkan orang lain yang didasarkan pada akal sehat, kejujuran, dan kebijaksanaan.

2. Manfaat berpikir kreatif

Berpikir kreatif erat kaitannya dengan memunculkan alternatif-alternatif. Dengan berpikir kreatif kita tidak hanya terpaku dengan satu alternative saja. Dengan berpikir kreatif kita dapat membuka kemungkinan-kemungkinan yang akan terjadi di masa depan, sehingga kita juga memiliki alternatif-alternatif cara menghadapi dimasa depannya.

Berpikir kreatif juga memudahkan kita untuk melihat, dan bahkan menciptakan peluangyang menunjang keberhasilan kita. Seringkali alasan seseorang tidak bertindak adalah karena tidak ada peluang. Padahal sesungguhnya peluang selalu ada didepan kita. Tinggal apakah kita jeli melihatnya atau tidak. Bahkan kalaupun peluang itu memang tidak ada, kita dapat menciptakan peluang asal kita mau berpikir kreatif.

\section{Kepraktisan Model Pembelajaran yang Berorientasi pada Kemampuan Perancangan dan Melakukan Eksperimen untuk Melatih Keterampilan Berpikir Siswa SMK}

Berdasarkan hasil pengamatan pada pelaksanaan pembelajaran berbasis perancangan dan praktek/eksperimen dapat diperoleh data bahwa pembelajaran dapat terlaksana dengan baik. Hal tersebut dapat dibuktikan dengan adanya 16 aspek kegiatan inti yang telah ditentukan dalam kriteria baik. Adapun untuk aspek ke 4 yaitu menjelaskan kepada siswa prosedur percobaan yang diambil dari materi latihan LKS dan aspek ke 8 yaitu menjelaskan kepada siswa 
agar mereka menganalisis dan mendiskusikannya terbukti sangat baik.

Berdasarkan hal tersebut maka dapat dismpulkan bahwa model pembelajaran model ini sangat praktis digunakan di SMK. Agar pembelajaran dapat berlangsung baik, Carin (1993) memberi saran agar (1) Membantu siswa memahami tujuan dari kegiatan yang dilakukan; (2) Memeriksa bahwa semua siswa memahami tujuan pembelajaran; (3) Sebelum melakukan kegiatan, menjelaskan dahulu cara bekerja yang aman; (4) Mengamati setiap siswa selama melakukan praktek; (5) Memberikan waktu yang cukup kepada siswa untuk mengembalikan alat dan bahan yang digunakan untuk ekperimen; (6) Melakukan diskusi hasil pengamatan selama eksperimen.

Pada penilaian waktu yang digunakan dalam pelaksanaan pembelajaran juga termasuk baik. Hal tersebut dapat dilihat ketika siswa dan guru melakukan eksperimen suasana kelas sangat antusias, jadi hal tersebut termasuk kriteria sangat baik. Kriteria inilah yang menunjang pendapat bahwa model pembelajaran berorientasi pada perancangan dan eksperimen sangat praktis digunakan.

Dengan merancang sesuatu, dapat melatih pola piker kreatif siswa. Misalnya merancang desain pagar minimalis atau merancang pintu jendela minimalis. Ketika melakukan eksperimen mereka melakukan pengamatan. Selanjutnya hasil pengamatan didiskusikan dengan teman kelompok dan antar kelompok, sehingga melatih siswa untuk berpikir logis dan kreatif. Mayers (1986), menyarankan bahwa dalam kegiatan diskusi dapat menguji kemampuan penalaran logis siswa dalam rangka membentuk karakter pemikir kritis. Selain itu Fascione (2010) menambahkan bahwa berpikir kritis siswa dapat diukur dari kegiatannya dalam mencari tahu, mencari kebenaran, bersikap sistematis, analitis, berpikiran terbuka, dan percaya diri dalam bernalar dan bijaksana.

Selanjutnya berdasarkan data penilaian tes akhir (ulangan harian) mereka telah mencapai ketuntasan belajar dan dapat mencapai KKM yang telah ditentukan. Oleh karena itu model pembelajran berorientasi pada perancangan dan eksperimen sangat praktis.

\section{Efektifitas Pelaksanaannya Selama Proses KBM}

Pelaksanaan model pembelajaran yang berorientasi pada kemampuan perancangan dan melakukan eksperimen untuk melatih keterampilan berpikir kritis siswa SMK. Model ini sangat membantu siswa untuk lebih cepat dan mudah memahami materi pembelajaran. Selain itu, dengan melakukan perancangan membantu siswa untuk 
menuangkan ide-ide yang dimilikinya.

sebagai berikut:

Hal tersebut, dikemukakan oleh beberapa siswa SMK Jetis

"Belajar merancang dapat melatih menuangkan suatu ide/gagasan baru, dan selanjutnya dengan melakukan eksperimen dapat memberikan pengalaman baru bagi siswa". Selain itu, dengan merancang, siswa lebih mengerti dan memahami sesuatu dengan berpikir secara mandiri. (Avinda, SMK Jetis Mojokerto)

Selain itu, Caterina dan Dini Yulia Asari menambahkan bahwa:

"Dengan merancang sesuai dengan keinginan sendiri maka lebih mudah memahami dan mengerti apa yang dieksperimenkan dan dirancang sebelumnya. Ya, hasilnya puas karena kami membuatnya dan mencoba serta mengeksperimenkan. Jadi, hasilnya, gejalanya dan dari awalnya.

Adapun hambatan-hambatan penyebab ketidak berhasilan selama proses belajar-mengajar dapat disebabkan oleh guru, siswa, serta sarana-prasarana dapat diuraikan sebagai berikut:

a) Hambatan dari siwa

1. Siswa belum pernah mengalami model pembelajaran berbasis praktek, sehingga siswa terlihat masih bingung dan kurang percaya diri pada saat melakukan percobaan dan merancang serta mempraktikannya.

2. Ada kelompok siswa yang kurang aktif selama pembelajaran.

3. Kurangnya fasilitas outdoor dan prasarana praktik disekolah baik berupa ruang laboratorium atau bengkel.

Berdasarkan hambatan yang terjadi selama KBM tersebut, maka dilakukan beberapa solusi yaitu:

1) Di awal, di tengah, dan di akhir pembelajaran, guru selalu mengingatkan kembali langkah-langkah KBM model pembelajaran berbasis perancangan dan praktik.

2) Guur memberikan kesempatan kepada siswa untuk mencoba merancang sesuatu dan mempraktikkannya, sehingga mereka dapat berpikir kritis dan kreatif.

3) Guru rajin mengingatkan siswa agar aktif berpartisipasi baik secara indiidu maupun secara kelompok selama perancangan dan praktik.

4) Guru menjelaskan bahwa keaktifan menjadi salah satu faktor penilaian. 
5) Mencari alternatif lokasi yang dapat menggantikan laboratorium, meskipun sederhana atau secara bergantian.

Berdasarkan implementasi model pembelajaran merancang dan mempraktikan di kelas X TGB 2 SMK Negeri Kudu, maka dapat diketahui bahwa dikelas tersebut model pembelajaran ini cukup efektif. Hal tersebut dibuktikan dengan hasil prestasi mereka untuk KD, $\operatorname{KD} 2$, KD 3, dan $\operatorname{KD~4,~nilai~rata-rata~di~atas~} \operatorname{KKM}(7,6)$ mata pelajaran Teknik Menggambar Konstruksi Kolom Beton Bertulang. Jumlah siswa 36 orang lulus di atas KKM 34 orang, dan 2 orang lulus remidi degan nilai 76 dan 57. Dua orang yang remidi karena nilai praktik KD 4 rancangan yang disusun gagal, sehingga nilai yang diperoleh rendah $(3,8)$ dan $(7,4)$.

Selanjutnya tingkat efektifitas pelaksanaan pembelajaran berbasis merancang dan praktik ini dapat dikatakan telah mencapai ketuntasan belajar meskipun 2 orang yang mendapatkan nilai rata-rata dibawah KKM telah mengikuti remidi untuk memperoleh ketuntasan belajar.

Pada mata pelajaran Teknologi Pengolahan Hasil Pertanian dengan SK: menerapkan dasar pengolahan dan pengawetan bahan hasil pertanian, KKM sekolah adalah 7,5. Hasil belajar 35 siswa tuntas semua sebab mereka lulus dengan nilai di atas $\operatorname{KKM}(7,5)$. Jadi mereka mendapatkan nilai rata-rata di atas KKM dan pembelajarannya juga tuntas, maka dapat disimpulkan model pembelajaran tersebut sangat efektif.

\section{Hasil Pengembangan Perangkat}

Tujuan yang ingin dicapai pada penelitian ini adalah tersedianya perangkat pembelajaran yang berorientasi pada kemampuan perancangan dan melakukan eksperimen untuk melatih ketrampilan berpikir kritis dan kreatif yang valid, praktis, efektif, dan dapat meningkatkan keterampilan berpikir kritis dan kreatif serta mencapai ketuntasan hasil belajar siswa. Berikut ini akan diuraikan pembahasan hasil penelitian.

\section{RPP}

RPP yang dikembangkan oleh peneliti adalah RPP untuk kompetensi Dasar. Mengaplikasi peran siswa dalam pokok bahasan las listrik dan las karbit. RPP yang dirancang terdiri dari tiga pertemuan, masing-masing dengan alokasi waktu 2 jam pelajaran (2x40 menit). RPP yang dikembangkan ini berorientasi pada model pembelajaran perancangan dan melakukan eksperimen yang bertujuan untuk 
melatihkan keterampilan berpikir kritis dan kreatif. Komponenkomponen dalam RPP yang dikembangkan meliputi: (1) Standar Kompetensi (SK); (2) Kompetensi Dasar (KD); (3) Indikator; (4) tujuan pembelajaran; (5) materi pembelajaran; (6) alokasi waktu; (7) metode pembelajaran; (8) langkah-langkah kegiatan pembelajaran.

Uraian kegiatan pembelajaran sesuai dengan langkah-langkah model pembelajaran pada kemampuan perancangan dan melakukan eksperimen untuk melatih ketrampilan berpikir kritis dan kreatif.

Saran revisi RPP antara lain: (1) masih perlu diperbaiki lagi dalam hal mengkaitkan materi baru dengan materi sebelumnya, (2) siswa tidak diinformasikan bahwa pada pertemuan kali ini pembelajaran dilakukan menggunakan model kemampuan perancangan dan melakukan eksperimen. Menuru Arrends (2001) bahwa pada sintaks pembelajaran perancangan (mengorientasikan siswa pada masalah), bahwa guru harus menjelaskan tujuan pembelajaran.

\section{LKS}

Lembar kegiatan siswa (LKS) merupakan panduan bagi siswa untuk belajar serta berlatih dalam memahami konsep-konsep yang hendak dipelajari pada sub pokok bahasan yang sedang dipelajari. LKS memuat sekumpulan kegiatan mendasar yang harus dilakukan oleh siswa untuk memaksimalkan pemahaman dalam upaya pembentukan kemampuan dasar sesuai indicator pencapaian hasil belajar yang harus dicapai.

LKS yang dikembangkan berorientasi pada pembelajaran pada kemampuan perancangan dan melakukan eksperimen untuk melatih ketrampilan berpikir kritis dan kreatif. Pada LKS yang dikembangkan ini, siswa dibimbing untuk menemukan konsep-konsep dengan melakukan kegiatan penemuan, menggunakan metode ilmiah. Selain melakukan kegiatan pengamatan dan percobaan, siswa mendiskusikan beberapa pertanyaan yang dapat melatih keterampilan berpikir kritis dan kreatif mereka.

\section{Buku Siswa}

Buku siswa yang digunakan pada penelitian ini dikembangkan berdasarkan kriteria pengembangan buku ajar menurut BSNP (2006). Buku siswa berisi uraian materi pembelajaran yang dapat dipergunakan oleh siswa sebagai panduan atau sumber belajar baik selama kegiatan pembelajaran di kelas maupun dipergunakan secara 
mandiri. Buku siswa yang dikembangkan mencakup pokok bahasan las listrik dan las karbit.

Di setiap sub pokok bahasan tersebut terdapat unsur kegiatan mandiri siswa berupa berpikir kritis, berpikir kreatif, cek konsep, percobaan-percobaan sederhana, dan pertanyaan-pertanyaan yang dapat memacu rasa ingin tahu siswa. Buku siswa ini diekmbangkan untuk melatihkan keterampilan berpikir kritis dan kreatif bagi siswa terhadap berbagai macam permasalahan yang berkaitan dengan kehidupan sehari-hari yang berkaitan dengan materi yang sedang diajarkan.

Penyajian buku siswa hendaknya memperhatikan keterkaitan dengan kehidupan nyata agar dapat membangkitkan semangat belajar siswa untuk mengaplikasikan informasi yang didapatkan, sehingga siswa memiliki peluang untuk menjadi kreatif dan inovatif. (BSNP, 2006).

\section{Keterampilan berpikir kritis}

Keterampilan berpikir kritis merupakan butiran tes yang digunakan untuk mengetahui tingkat keterampilan berpikir kritis siswa sebelum dan setelah mengikuti proses pembelajaran menggunakan perangkat pembelajaran yang dikembangkan. Menurut Corebima (2001), aspek-aspek evaluasi yang harus diimplementasikan agar dapat mendorong perkembangan berpikir kritis salah satunya yaitu untuk tes hendaknya menggunakan bentuk essay.

Penilaian keterampilan berpikir kritis mengacu pada rubric yang telah dikembangkan. Ennis (2001) menjelaskan bahwa assesmen terhadap kemampuan berpikir kritis antara lain bertujuan untuk 1) mendiagnosis tingkat berpikir kritis siswa; 2) memberi umpan balik keberanian berpikir kritis siswa; 3) memberi motivasi agar siswa mengembangkan kemampuan berpikir kritisnya; dan 4) memberi informasi kepada guru tentang pengaruh pengajarannya tentang berpikir kritis. Guru dapat membuat tes berpikir kritis dalam bentuk pertanyaan open-ended yang disesuaikan dengan aspek-aspek berpikir kritis khusus yang diinginkan.

Tes keterampilan berpikir kreatif merupakan instrument yang digunakan untuk mengetahui tingkatan kemampuan berpikir kreatif yang dimiliki oleh siswa. Dalam penelitian ini, tes keterampilan berpikir kreatif diberikan di awal dan di akhir pembelajaran. Hal tersebut dilakukan dengan menggunakan perangkat pembelajaran kemampuan perancangan dan melakukan eksperimen untuk melatih ketrampilan berpikir kritis dan kreatif siswa. 
Menurut munandar (2009) bahwa salah satu kendala terhadap gerakan kreativitas terletak pada ala-alat ukur yang biasanya dipakai di sekolah-sekolah yaitu tes inteligensi tradisional yang mengukur kemampuan siswa untuk belajar, dan tes prestasi belajar untuk menilai kemajuan siswa selama program pendidikan. Baik tes inteligensi maupun tes prestasi belajar kebanyakan hanya meliputi tugas-tugas yang harus dicari satu jawaban yang benar (berpikir konvergen). Kemampuan berpikir divergen dan kreatif, yaitu menjajaki berbagai kemungkinan jawaban atas suatu masalah, dan jarang diukur.

Tes keterampilan berpikir kreatif yang telah dikembangkan tidak diuji validitasnya. Hal tersebut dikarenakan tes ini dikembangkan dengan mengadaptasi tes berpikir kreatif yang dikembangkan oleh munandar (2009). Jadi tes tersebut sudah valid tes keterampilan berpikir kreatif diberikan dalam dua bentuk, yaitu tes kreativitas verbal dan tes kreativitas produk. Tes kreatvitas verbal terdiri dari 6 sub-tes yang semuanya mengukur dimensi operasi berpikir divergen.

\section{Lembar Penilaian Keterampilan Berpikir Kritis Dan Kreatif}

Instrumen yang digunakan untuk mengukur keterampilan berpikir kritis siswa yaitu dengan menggunakan lembar penilaian keterampilan berpikir kritis. Lembar penilaian ini berupa tes keterampilan berpikir kritis yang terdiri dari 9 soal, digunakan untuk menilai tingkat keterampilan berpikir kritis siswa. Pemberian skor dengan menggunakan rubrik berdasarkan jawaban tes tertulis. Arikunto (2006) mengungkapkan bahwa tolak ukur pendidikan dapat diketahui dengan adanya evaluasi, artinya jika siswa diharapkan mampu berpikir kritis maka soal-soal yang diberikan juga harus melatih kemampuan keterampilan berpikir kritis.

Lembar penilaian keterampilan berpikir kreatif berupa tes kreativitas verbal yang terdiri dari 6 sub-tes yang semuanya mengukur dimensi operasi berpikir divergen, dan tes kreativitas produk yang meminta siswa untuk membuat desain penyambungan pipa dengan memanfaatkan bahan-bahan yang disediakan oleh guru. Lemabar penilaian keterampilan berpikir kreatif ini digunakan untuk mengamati dan menilai tingkat keterampilan berpikir kreatif siswa, yang sudah diuji dengan menggunakan instrumen tes kreativitas verbal dan tes kreativitas produk. Instrumen tersebut dinilai dengan menggunakan lembar penilaian berpikir kreatif, yaitu berupa rubrik penilaian untuk tes kreativitas verbal dan tes kreativitas produk. Lembar penilaian ini tidak diuji validitasnya. Hal tersebut dikarenakan lembar penilaian ini dikembangkan dengan mengadaptasi 
keterampilan berpikir kreatif yang dikembangkan oleh Munandar (2009), jadi lembar penialian tersebut sudah valid. Selain menggunakan instrumen tes kreativitas verbal, penilaian keterampilan berpikir kreatif siswa juga diukur dengan menggunakan instrumen tes kreativitas produk yang dikembangkan oleh peneliti, dan skala sikap kreatif yang dikembangkan oleh Mustami (2007).

\section{Keterbacaan LKS dan Buku Siswa}

\section{Keterbacaan LKS}

Lembar penilaian keterbacaan LKS berbentuk paragrafparagraf sampel dengan jumlah keseluruhan 250 kata kemudian mengalami penghilangan sebanyak 50 kata. Penghilangan setiap jarak 4 samapi 6 kata, yang kemudian harus diisi oleh siswa sebelum pembelajaran dilakukan.

\section{Keterbacaan Buku Siswa}

Lembar penilaian keterbacaan buku siswa berbentuk paragrafparagraf sampel dengan jumlah keseluruhan 250 kata kemudian mengalami penghilangan sebanyak 50 kata. Penghilangan setiap jarak 4 samapi 6 kata, yang kemudian harus diisi oleh siswa sebelum pembelajaran dilakukan.

Menurut BSNP (2006) bahwa informasi yang disajikan dalam buku siswa hendaknya memberikan arti bagi siswa (meaningful), memiliki aspek keterbacaan yang tinggi, menarik dan memikat serta isi bahasanya mampu mengoptimalkan daya pikir siswa.

\section{Kesulitan LKS}

Pengujian kesulitan LKS dilakukan oleh 10 orang siswa. Instrumen ini berbentuk kolom pengisian jumlah kalimat dalam LKS yang tidak dapat dipahami oleh siswa. Dari sini dapat diperoleh informasi bahwa kesulitan LKS sangat rendah atau sangat mudah dipahami.

\section{Kesulitan Buku Siswa}

Pengujian kesulitan buku siswa dilakukan oleh 10 orang siswa. Instrumen ini berbentuk kolom pengisian jumlah kalimat dalam buku siswa yang tidak dapat dipahami oleh siswa. Dari sini dapat diperoleh informasi bahwa kesulitan buku siswa sangat rendah atau sangat mudah dipahami. 
Siti Annijat Maimunah - Peningkatan Mutu SKL Siswa SMK Melalui Model yang Berorientasi pada Kemampuan Perancangan dan Melakukan Eksperimen untuk Melatih Ketrampilan Berpikir Kritis

\section{Pelaksanaan RPP}

Berdasarkan data hasil pengamatan keterlaksanaan RPP yang ada diperoleh informasi bahwa semua fase pembelajaran pada pertemuan I, II, dan III telah terlaksana. Pada aspek kegiatan awal terdapat lima aspek yang diamati, termasuk dalam kriteria baik. Begitu pula apabila kita lihat dari masing-masing aspek, menunjukkan kriteria baik. pada aspek kegiatan inti terdapat 16 aspek yang diamati, termasuk dalam kriteria baik. Secara umum tiap aspek berada pada kriteria baik, kecuali pada aspek 4 yaitu menjelaskan kepada siswa prosedur pada percobaan pada LKS, dan aspek 8 yaitu meminta siswa untuk berdiskusi menganalisis data hasil percobaan dengan cara menjawab pertanyaan-pertanyaan yang ada di LKS secara berkelompok, kedua aspek tersebut termasuk dalam kriteria sangat baik. Pada aspek kegiatan penutup meliputi 2 aspek yang diamati, termasuk dalam kriteria baik.

Agar pembelajaran dengan perancangan dan menemukan eksperimen mencapai tujuan pembelajaran, Carin (1993) menyarankan agar: (1) Membantu siswa memahami tujuan dari kegiatan yang dilakukan; (2) Memeriksa bahwa semua siswa memahami tujuan kegiatan dan prosedur kegiatan yang harus dilakukan; (3) Sebelum kegiatan dilakukan, menjelaskan dahulu cara bekerja yang aman; (4) Mengamati setiap siswa selama melakukan kegiatan; (5) Memberikan waktu yang cukup kepada siswa untuk mengembalikan alat dan bahan yang digunakan;(6) Melakukan diskusi tentang kesimpulan untuk setiap jenis kegiatan.

Pada aspek pengelolaan waktu termasuk dalam kriteria baik. Aspek pengamatan suasana kelas menilai antusias siswa dan antusias guru. Untuk antusias siswa termasuk dalam kriteria sangat baik, sedangkan untuk antusias guru termasuk dalam kriteria baik.

\section{Hambatan-Hambatan yang ditemukan selama pelaksanaan pembelajaran dengan menerapkan perangkat pembelajaran yang dikembangkan}

Beberapa hambatan yang dialami selama proses belajar mengajar yang muncul baik dari faktor siswa, guru, maupun sarana prasarana. Beberapa hambatan selama proses belajar mengajar antara lain; 1) siswa belum pernah melakukan proses pembelajaran dengan menggunakan model perancangan dan melakukan eksperimen serta proses pembelajaran yang melatih keterampilan berpikir kritis dan kreatif, sehingga siswa masih sedikit bingung dan kurang percaya diri baik dalam melakukan kegiatan pembelajaran maupun dalam 
berpendapat, ada kelompok siswa yang kurang aktif selama pembelajaran dan kurangnya fasilitas outdoor di sekolah. Beberapa hambatan tersebut diatasi dengan cara pada pertemuan berikutnya diawal, ditengah, dan diakhir. Pembelajaran guru selalu mengingatkan kembali langkah-langkah kegiatan pembelajaran dengan menggunakan model perancangan dan eksperimen, guru memberikan kesempatan kepada siswa untuk dapat berpikir kritis dan kreatif, dan selalu memberikan semangat terhadap hal tersebut. Guru rajin mengingatkan siswa agar aktif berpartisipasi aktif baik di dalam kelompoknya maupun ketika berdiskusi. Guru menjelaskan bahwa keaktifan menjadi salah satu faktor penilaian. Dengan diskusi, siswa dapat mengembangkan kemampuan berpikir kritisnya seperti yang disarankan oleh Meyers (1986), karena dalam kegiatan diskusi dapat menguji kemampuan penalaran logis mereka dalam rangka membentuk karakter pemikir kritis (Fascione, 2010) yaitu: 1) mencari tahu (inguisitive); 2) mencari kebenaran (truth seeking); 3) bersikap sistematis (systematic); 4) menganalisis (analytical); 5) berpikir terbuka (open minded); 6) percaya diri dalam bernalar (confident in reasoning); dan bijaksana (judicious). Solusi yang terakhir yaitu mencari alternatif lokasi outdoor yang sesuai untuk melakukan kegiatan penemuan, terutama pada kegiatan pada LKS.

\section{Ketuntasan Hasil Belajar Siswa}

Berdasarkan hasil analisis tes hasil belajar kognitif dapat diperoleh informasi bahwa penerapan pembelajaran dengan menggunakan perangkat pembelajaran yang berorientasi pendekatan perancangan dan eksperimen dapat menuntaskan seluruh tujuan pembelajaran aspek kognitir dengan proporsi jawaban siswa pada ujian akhir (posttest) untuk masing-masing tujuan pembelajaran lebih besar daripada kriteria ketuntasan minimal. Pada uji awal (pretest) dari 14 tujuan pembelajaran hanya 1 tujuan pembelajaran yang tuntas.

\section{Keterampilan Berpikir Kritis}

Penguasaan keterampilan berpikir kritis siswa selama proses pembelajaran dengan menggunakan perangkat pembelajaran yang dikembangkan ini di analisis dengan menggunakan instrumen berupa lembar penilaian keterampilan berpikir kritis. Analisis keterampilan berpikir kritis siswa dilakukan menggunakan analisis sensitivitas. Hasil keterampilan berpikir kritis siswa diperoleh dari nilai rata-rata ketercapaian siswa dalam mengerjakan soal-soal berbentuk essay berupa soal terbuka. Nilai keterampilan berpikir kritis dinilai 
beradasarkan hasil keterampilan berpikir kritis.

Berdasarkan nilai yang ada dapat dikemukakan bahwa secara umum penguasaan keterampilan berpikir kritis siswa meningkat setelah melaksanakan pembelajaran dengan menggunakan perangkat pembelajaran yang dikembangkan. Data tersebut menunjuukan bahwa pembelajaran dengan menggunakan pembelajaran perancangan dan eksperimen memiliki beberapa keuntungan, diantaranya dapat memacu rasa ingin tahu siswa, memotivasi mereka untuk melanjutkan pekerjaannya sehingga mereka menemukan jawabannya, memecahkan masalah secara mandiri dan keterampilan berpikir kritis (Nur, 2000). Hal ini sejalan dengan Akinbobola (2010) yang merekomendasikan bahwa guru seharusnya berusaha keras untuk menerapkan pendekatan konstruktivisme melalui perancangan dan eksperimen dengan harapan agar mengarahkan siswa pada aktivitas problem solving, pembelajaran mandiri, belajar berpikir kritis, dan berpikir kreatif, daripada sekedar mengingat.

\section{Keterampilan Berpikir Kreatif}

Tes yang diberikan dalam bentuk tes kreativitas verbal dan tes kreativitas produk. Keterampilan berpikir kreatif ini dinilai dengan menggunakan lembar penilaian keterampilan berpikir kreatif. Selain menggunakan tes kreativitas verbal dan tes kreativitas produk, penilaian keterampilan berpikir kreatif siswa dilakukan menggunakan skal kreatif yang dikembangkan oleh Munandar (1977) dalam Mustami (2007).

Keterampilan berpikir kreatif siswa merupakan hasil analisis dari format penilaian antara lain: tes kreativitas verbal, tes kreativitas produk, dan skala sikap kreatif. Tes kreativitas verbal yang diberikan pada siswa dikembangkan berdasarkan tes kreativitas yang dikembangkan oleh Munandar (2009).

Berdasarkan hasil analisis dapat kita simpulkan bahwa perangkat pembelajaran dengan menggunakan perancangan dan eksperimen dapat melatih keterampilan berpikir kreatif. Menurut Munandar (1999) bahwa mengajar dengan eksperimen selain berkaitan dengan perancangan juga bisa meningkatkan kemampuan berpikir kreatif. Keterampilan berpikir kreatif siswa dianalisis dengan mengacu pada 5 indikator yaitu: kelancaran, kelenturan, orisinalitas, elaborasi, dan menilai. Berdasarkan data yang ada dapat dikemukakan bahwa secara umum penguasaan keterampilan berpikir kreatif siswa meningkat setelah melaksanakan pembelajaran dengan menggunakan perangkat pembelajaran yang dikembangkan. 
Lembar penilaian keterampilan berpikir kreatif selanjutnya adalah lembar tes kreativitas produk, tes ini meminta siswa untuk membuat produk berupa penyambungan dengan menggunakan las karbit dan dengan memanfaatkan bahan-bahan yang disediakan oleh guru. Pemberian nilai pada tes ini dengan menggunakan rubrik tes kreativitas produk yang telah dikembangkan.

Berdasarkan data yang ada dapat diketahui bahwa rata-rata siswa mengalami peningkatan nilai tingkat berpikir kreatifnya. Dengan terampil memecahkan masalah, maka siswa telah mencapai hasil belajar yang baik (Gagne, 1978). De Cecco (1977) dalam Ibrahim (1985) mengatakan bahwa pemecahan masalah (problem soving) merupakan istilah lain untuk kreativitas atau berpikir kreatif. Hal ini menunjukkan eratnya hubungan antara kreativitas dan pemecahan masalah. Pendapat ini diperkuat oleh Guilford dalam Munandar (2009) bahwa kreativitas atau berpikir kreativ sebagai kemampuan untuk melihat bermacam-macam kemungkinan penyelesaian terhadap suatu masalah. Hasil penelitian Rohim (2012), bahwa pembelajaran dengan menggunakan perancangan dan eksperimen dapat meningkatkan kemampuan berpikir kreatif siswa.

Selain menggunakan tes kreativitas verbal dan tes kreativitas produk, keterampilan berpikir kreatif juga dinilai dengan menggunakan berupa skala sikap kreatif. Instrumen ini berupa angket skala sikap kreatif yang disusun dan dimaksudkan untuk mengetahui kecenderungan pada reaksi positif atau negatif terhadap perbuatan kreatif yang dimiliki siswa. Dalam hal ini, kreativitas dipandang sebagai suatu proses yang berkaitan dengan kemampuan untuk mengungkapkan gagasan positif, negatif, dan netral yang dibagikan secara acak supaya siswa dapat memenuhi respon yang wajar dan sungguh-sungguh. Ietem-item dalam tes ini dikembangkan berdasarkan nilai-nilai dari tokoh-tokoh yang telah diidentifikasi sebagai kreatif. Nilai-nilai tersebut antara lain: keterbukaan terhadap pengalaman baru dan luar biasa, fleksibel dalam berpikir, menyenangi kebebasan dalam berpikir dan pernyataan, menghargai fantasi, percaya terhadap gagasan sendiri, serta bebas dalam penilaian.

Berdasarkan data yang ada dapat dijelaskan bahwa kriteria kemampuan berpikir kreatif siswa yang mengacu pada angket skala sikap kreatif mengalami peningkatan dengan tingkatan kriteria kemampuan berpikir kreatif yang bervariasi, ada yang tinggi, sedang, dan kurang. Hasil ini diperkuat oleh Garner (2012) yang mengungkapkan bahwa ketika kita memerlukan jalan keluar untuk 
menyelesaikan suatu masalah yang sulit dipecahkan, kita butuh untuk lebih kreatif serta membutuhkan berpikir dan menentukan solusi, mengembangkan pemikiran baru dan solusi baru, dengan menggunakan otak kanan.

\section{Respon Siswa}

Respon siswa terhadap proses belajar mengajar dengan menerapkan perangkat pembelajaran model perancangan dan eksperimen dapat diperoleh informasi bahwa keseluruhan siswa tertarik dengan materi pelajaran, bahan ajar, LKS, suasana belajar, dan cara-cara guru mengajar. hal ini ditunjukkan oleh respon siswa pada masing-masing komponen. Selain siswa berpendapat tertarik terhadap komponen-komponen tersebut, siswa juga berpendapat bahwa komponen-komponen tersebut baru, hal ini dibuktikan dengan ratarata siswa yang setuju dengan pendapat tersebut.

Komponen-komponen antara lain bahasa dalam buku, materi buku, contoh-contoh soal, LKS, dan cara guru mengajar dengan mudah dapat dipahami oleh siswa. Hal ini dibuktikan dengan siswa yang berpendapat demikian. Respon siswa terhadap pemahaman komponen bahasa dalam buku, materi buku, contoh-contoh soal, LKS, dan cara guru mengajar tinggi. Data respon siswa juga memberikan gambaran bahwa siswa setuju apabila pada pokok bahasan selanjutnya menggunakan model pembelajaran perancangan dan eksperimen, dan mengajarkan keterampilan berpikir kritis dan kreatif, hal ini dibuktikan dengan rata-rata nilai yang baik. Hal ini memperkuat pendapat dari Cari (1993) bahwa perancangan dan eksperimen mempunyai keuntungan salah satunya untuk memotivasi diri siswa. Sifat pembelajaran eksperimen memberikan lingkungan bebas dari motivasi ekstrinsik (Suchman, 1962). Respon siswa yang setuju terhadap kedua komponen bahwa pembelajaran dengan menggunakan model pembelajaran perancangan dan eksperimen dapat mengajarkan keterampilan berikir kritis dan kreatif adalah keseluruhan. Menurut teori motivasi, ketertarikan dan keberminatan siswa terhadap pelajaran dan metode pembelajaran dapat meningkatkan motivasi siswa untuk belajar (Nur, 2008).

Keseluruhan siswa senang terhadap penjelasan guru pada saat kegiatan belajar mengajar berlangsung, dan terhadap bimbingan guru pada saat siswa memecahkan masalah melalui eksperimen dan pengamatan. Siswa cukup senang terhadap keterampilan berpikir kritis, hal ini dibuktikan dengan rata-rata siswa yang merasa senang. Respon siswa yang senang terhadap keterampilan berpikir kritis 
antara lain merumuskan masalah, memberi argumen atau pendapat, melakukan analisis, dan merumuskan kesimpulan. Data respon siswa juga memberi gambaran bahwa penilaian siswa terhadap keterampilan berpikir kreatif sangat senang, hal ini dibuktikan dengan hampir keseluruhan siswa yang merasa senang terhadap keterampilan berpikir kreatif. Respon siswa yang senang terhadap keterampilan berpikir kreatif antara lain mencetuskan banyak gagasan dan jawaban; menghasilkan gagasan dan jawaban yang bervariasi; melahirkan ungkapan yang baru dan unik; memperkaya dan mengembangkan suatu gagasan atau produk; dan mengambil keputusan terhadap situasi yang terbuka, tidak hanya mencetuskan gagasan tetapi juga melaksanakannya, masing-masing keseluruhan siswa. Siswa merasa mudah untuk menjawab butir soal atau tes hasil belajar, hal ini dibuktikan dengan keseluruhan nilai siswa yang baik.

Secara keseluruhan, siswa memberikan respon positif terhadap pembelajaran. Respon positif ini menunjukkan bahwa siswa antusias dengan pembelajaran yang disajikan. Hal ini dapat memotivasi siswa untuk meningkatkan perhatian dan membuat mereka terlibat dalam pengalaman pembelajaran yang menyenangkan dan bermakna (Nur, 2008). Dengan menggunakan model pembelajaran perancangan dan eksperimen, siswa akan terlibat aktif dalam pembelajaran. Kardi (1997) mengemukakan bahwa perancangan dan eksperimen merupakan model pembelajaran yang memberi kesempatan dan menuntut siswa terlibat secara aktif dalam mencapai tujuan pembelajaran.

\section{Kesimpulan}

Berdasarkan hasil implementasi perangkat pembelajran yang dikembangkan dilapangan, dapat disimpulkan bahwa perangkat pembelajaran berorientasi pada kemampuan perancangan dan melakukan eksperimen untuk melatih ketrampilan berpikir kritis dan kreatif yang valid, praktis, efektif, dan dapat meningkatkan keterampilan berpikir kritis dan kreatif serta mencapai ketuntasan hasil belajar siswa. Respon siswa positif setelah mengikuti pembelajaran dengan menerapkan perangkat pembelajaran berorientasi pada kemampuan perancangan dan melakukan eksperimen untuk melatih ketrampilan berpikir kritis dan kreatif siswa. 


\section{DAFTAR PUSTAKA}

Arrends, R. 2001. Learning to Teach. New York: Mc. Graw Hill Book Company.

Arikunto, S. 2006. Prosedur Penelitian, Suatu Pendekatan Praktis. Jakarta: Rineka Cipta.

Akinbobola, A. O. And Afolabi, F. 2010. “Constructivistic Practices through Guided Discovery Approach: The Effect on Student' Cognitive Achievement in Nigerian Senior Secondary School Physics" Eruasian J. Phys. Chem. Educ. Vol 2 No 1.

Bogdan dan Bigklen. 1982. Qualitative Research. New York: Oxford.

BNSP. 2006. Naskah Instrumen Penilaian Buku Teks Pelajaran Pendidikan Dasar Menengah. Jakarta: BNSP.

Corebima, A. D. 2001. Pola Pengembangan Lembar PBMP (TEQ) dalam Pembelajaran IPA-Biologi. Makalah disajikan pada Pelatihan dan Lokakarya PBMP di Universitas Negeri Malang, Malang.

Caccavo, F. 2009. Teaching Undergraduates to think Like Sciientist.

Depdiknas. 2006. Standar Kompetensi Lulusan untuk Siswa Pendidikan Dasar dan Menengah. Jakarta.

Ennis, R. H. 1993. Critical Thinking Assesment: Theory In to Practice.

Ennis, R. H. 2001. Critical Thinking Assesment Theory Into Practice. College of Education. The Ohio State University. Vol 32. Number 3. Summer 1993.

Garner, E. 2012. Thinking Skills, Using Your Brain in the Information Age. London: Eric Garner \& Ventus Publishing ApS.

Ibrahim, M. 2002. Pelatihan Terintegrasi Berbasis Kompetensi Guru Mata Pelajaran Biologi Pengembangan Perangkat Pembelajaran. Jakarta: Departemen Pendidikan Nasional.

Ibrahim, M. 2008. Pembelajaran Inovatif IPA Melalui Pemaknaan. Jakarta: Depdiknas Balitbang-Puslitjaknov.

Johnson, S. 2010. Where Good Ideas Come From. New York: Riverhead books.

Kardi, S. 1997. Direct Instruction, Penemuan Terbimbing, dan Investigasi Kelompok. PPs IKIP Surabaya. 
Park, H. 2004. The effects of divergent production activities with math inquiry and think aloud.

Munandar, U. 1999. Pengembangan Kreativitas Anak Berbakat. Jakarta: Rineka Cipta.

Munandar, U. 2009. Pengembangan Kreativitas Anak Berbakat. Jakarta: Rineka Cipta.

McGregor, D. 2007. Thinking; Developing Learning. A Guide to ThinkingSkills in Education. McGrawHill: Open University Press.

Mustami, MK. 2007. "Pengaruh Model Pembelajaran Synectics yang Dipandu Minds Maps dan Kooperatif STAD terhadap Kemampuan Berpikir Kreatif, Sikap Kreatif, dan Penguasaan Materi Biologi Siswa SMP Kota Makassar". Disertasi Doktor, Universitas Negeri Malang.

Nur, M. Dan Wikandari, P.R. 2000. Penagjajaran Berpusat Kepada Siswa dan Pendekatan Konstruktivistik dalam Pengajaran. Surabaya: Pusat sains dan Matematika Sekolah (PSMS) UNESA.

Nur, P. D. 2011. Modul Ketrampilan Proses Sains. Surabaya: PSMS.

Suchman, R. 1962. The Elementary School Training Program in Scientific Inquiry. Report to The U.S. Office of Education. Urbana: University of illionis.

Supramono. 2000. Pendekatan Inquiry dengan Alat-Alat Sederhana Dalam Pembelajaran Fisika. Foton.

Slameto. 2003. Belajar dan Faktor-Faktor yang Mempengaruhi. Jakarta : PT. Rineka Cipta.

Santrock, J.W. 2011. Child development (12thed.). New York: McGraw-Hill Companies. 